\title{
Art imitating high-energy physics
}

Munich

Some of Europe's leading conceptual artists are taking part in an extraordinary cultural experiment at CERN, the European Laboratory for Particle Physics.

The artists, who include Turner Prize winners Anish Kapoor and Richard Deacon, have been brought to CERN to learn about high-energy physics and will respond by creating an original piece of art during this year. These artworks will be exhibited at galleries across Europe next year in a roadshow called "Signatures of the Invisible" — a reference to the fact that subatomic events can only be des cribed by their mathematical signatures.

So far, most of the artists seem to have been more impressed by CERN's physical environment, its engineering tools and exotic materials, than by the details of theoretic physics. After visiting CERN, Deacon said: "We need to listen to each other, but not necessarily to understand. The misunderstanding in both directions can be creative."

British artist Patrick Hughes is known for his work on 'reverse perspective'. His threedimensional scenes appear to shift dramatically in perspective as observers move around them. Hughes says he may build a large three-dimensional model depicting the huge doors to CERN's subterranean experimental chambers, opening onto a view of the mountains that surround Geneva. Deacon, a sculptor, says he is toying with ways of

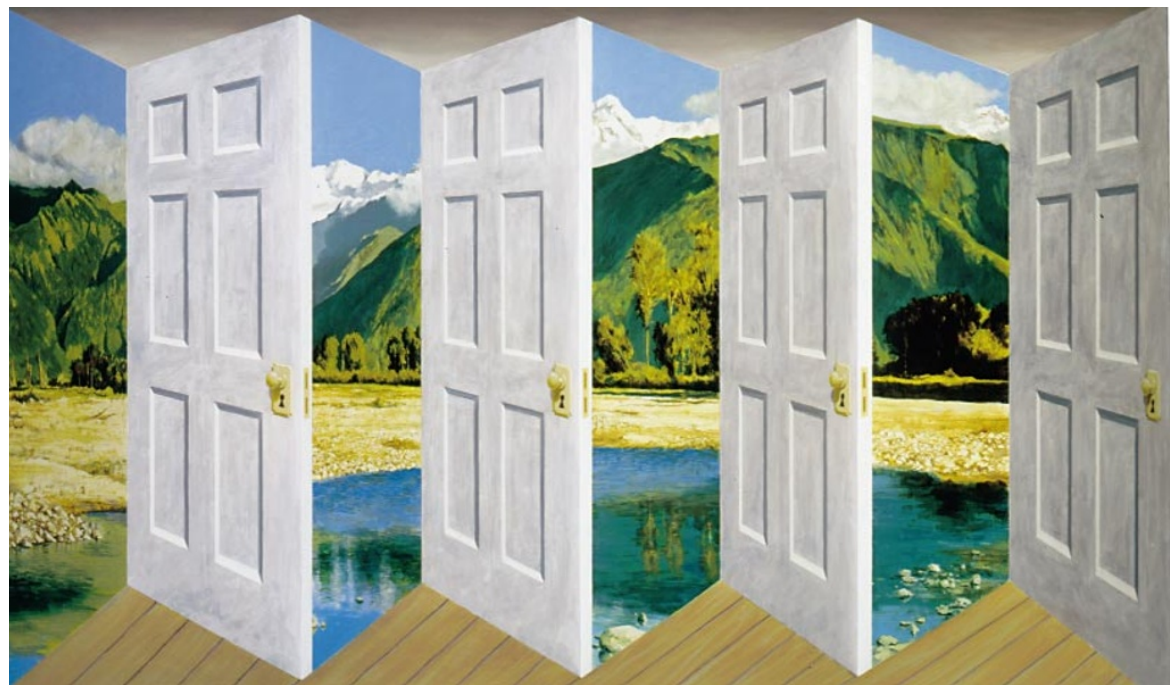

A new perspective: this work, Hoppera (1999), is by Patrick Hughes, who is part of the CERN project.

exploring "the edges of things". He is impressed with CERN's exotic materials "not just for their properties, but also for their metaphoric significance".

However, some of the artists are getting to grips with physics. Bartolomeu dos Santos, a Portuguese artist, has produced many pieces of public art by etching the surface of materials. He is using CERN's electron welding facility, normally used to produce distortion-free welds for high-precision instruments, to etch representations of event displays and theoretical formulae into steel.

Film-maker Ken McMullen, who is organizing the project, will be addressing another phenomenon of physics: crumpling. His film will record the way that metals exposed to the same pressure under the same conditions always crumple in a different way. "The only variable is time," says McMullen.

CERN director-general Luciano Maiani admits to being bemused by the project, but says he is "happy to let it carry on around CERN's periphery".

Alison Abbott

\section{Older women scientists fight USGS over layoffs}

\section{San Diego}

Women scientists who lost their jobs at the US Geological Survey (USGS) office in Denver, Colorado, during a major layoff have filed a discrimination complaint with federal authorities. They allege that they were targeted for discharge because of their age and gender.

This is the latest in a series of legal fights that have continued since the 1995 'reduction in force', when 525 of the 1,850 scientists in the USGS geology division, which is spread over different sites, were laid off, retired or diverted to other jobs. Since then, more scientists have left.

The complaint was filed with the Equal Employment Opportunity Commission (EEOC) in January by two former scientists on behalf of up to 20 women.

The two women - Constance Throckmorton and Kathryn Nichols claim that female geologists older than $\mathbf{4 0}$ were "affected at a rate nearly twice that of male counterparts". Of the $\mathbf{4 4}$ women scientists in the Denver division, 45 per cent were laid off, while only 23 per cent of the 215 men lost their jobs, they say.

Nichols, who had worked at the USGS for nineteen years, was a year from retirement eligibility when she was laid off. She says that her history of challenging "an old-boy network" had made her unpopular with top USGS officials who "didn't want anyone challenging old [scientific] conclusions". Nichols, who received her doctorate at Stanford University, says: "I was an intellectual threat."

In support of their belief that uneconomical overstaffing was not the genuine reason for the redundancies, the women cite an e-mail which USGS Chief Geologist, Patrick Leahy sent to all geological staff in early January, in which he says that the "top concern" of the USGS is to recruit new scientific staff, which the agency is doing by hiring a "modest" number of postdoctoral fellows.

Thomas Fouch, the regional geologist in Denver, says that despite the sharp blow to morale caused by the layoffs, the USGS is "in good [scientific] shape", in contrast to allegations by some dissatisfied staff. The number of scientific publications published by the USGS has not decreased since 1995 , he says.

The move was made necessary by budget cuts, he claims. He adds that the workforce reductions have allowed the USGS to implement modern employment standards because future staff will be hired on shortterm contracts. The laid-off USGS scientists thought they had "a job for life [as] an entitlement", says Fouch.

USGS director Charles Groat and other top officials at the agency's headquarters in Virginia declined to comment on the discrimination claim. The EEOC will review the allegation, conduct a hearing and issue a ruling. The women can take their complaint to the federal court if they are dissatisfied with the ruling.

Meanwhile, one long-time geologist in Denver privately describes the current situation as follows: "The mood is very pessimistic; morale is low." Rex Dalton 